\title{
Factors affecting the concentration of soluble tumour necrosis factor- $\alpha$ receptor type I in the blood serum of patients with localized scleroderma
}

\author{
Martyna Zbiciak-Nylec¹, Dominika Wcisło-Dziadecka², Ligia Brzezińska-Wcisło³
}

${ }^{1}$ Andrzej Mielęcki Silesian Independent Public Clinical Hospital, Katowice, Poland

${ }^{2}$ Chair of Cosmetology, School of Pharmacy with the Division of Laboratory Medicine in Sosnowiec (SPLMS in Sosnowiec), Medical University of Silesia, Katowice, Poland

${ }^{3}$ Department of Dermatology, School of Medicine in Katowice (SMK in Katowice), Medical University of Silesia, Katowice, Poland

Adv Dermatol Allergol 2020; XXXVII (4): 524-530

DOI: https://doi.org/10.5114/ada.2020.98239

\begin{abstract}
Aim: The aim of the study was to assess of sTNF $\alpha$ R1 concentration in the serum of patients with localized scleroderma (in comparison with a control group).

Material and methods: This was a prospective study. The patients with localized scleroderma were divided into two groups: 21 persons treated with PUVA therapy and 20 persons treated with procaine penicillin. In the case of the patients treated with intramuscularly administered procaine penicillin (dose: 2,400,000 IU/day), achievement of a total dose of at least 30 million IU/day was considered as the end of the therapy. In the group of patients treated with photochemotherapy, the single initial dose during a PUVA session was $0.5 \mathrm{~J} / \mathrm{cm}^{2}$ and it was increased by $0.5 \mathrm{~J} / \mathrm{cm}^{2}$ every other day to reach the maximum value of $10 \mathrm{~J} / \mathrm{cm}^{2}$, depending on the clinical condition. The study involved three sessions a week.

Results: sTNF $\alpha$ R1 concentration in the serum of patients with localized scleroderma was significantly higher in comparison with the control group and correlated with the skin damage index. The difference in the determined particle level was higher in the group of patients undergoing photochemotherapy (median: 106.25 $\mathrm{ng} / \mathrm{ml}$ ) than in the group taking penicillin (median: $81.50 \mathrm{ng} / \mathrm{ml}$ ). Patients treated with PUVA sessions demonstrated a greater decrease in STNF $\alpha$ R1 concentration and an improvement of the clinical condition after therapy completion.

Conclusions: The obtained results suggest a potential role of sTNF $\alpha$ R1 in the pathogenesis of localized scleroderma.
\end{abstract}

Key words: localized scleroderma, TNF $\alpha$ R1, PUVA.

\section{Introduction}

Scleroderma is a chronic connective tissue disease of unknown aetiology. Concomitant immunological disorders with lesions of an inflammatory and subsequently vascular nature are suggested in this respect. Progressive fibrosis is considered as the final stage in the pathogenetic chain of the disease. The condition is not classified as genetically conditioned, but hereditary factors may actually be involved in its development. Qualitative disturbances of the connective tissue and collagen metabolism are not observed. One distinguishes two main clinical forms of the disease: systemic scleroderma (which has two subtypes: the localized form and the generalized form) and localized scleroderma (also referred to as mor- phea and LoS) [1]. LoS lesions are usually confined to the skin and the subcutaneous tissue, which distinguishes localized scleroderma from systemic scleroderma as the fibrosis process in the latter also affects internal organs. Nonetheless, the diseases have many common features such as dominant activity of Th2 lymphocytes during an inflammatory reaction, endothelial cell dysfunction and a similar histopathological picture. Many authors reckon that those two disease entities are closely related, but should be investigated separately [2-8].

The available publications present results of numerous studies concerning increased concentrations of various particles related to the pathogenesis of localized scleroderma in the blood serum of patients with LoS in comparison with control groups as well as their relation to the

Address for correspondence: Martyna Zbiciak-Nylec MD, Andrzej Mielęcki Silesian Independent Public Clinical Hospital, 20/24 Francuska, 40-027 Katowice, Poland, phone/fax: +48 32 256-11-82, 698633 332, e-mail: zbita23@o2.pl Received: 2.10.2018, accepted: 4.01.2019. 
clinical form of the disease, the number of skin lesions, the number of body areas affected by the disease and disease duration [1, 3, 8-11]. However, only a few studies take into account all those parameters simultaneously.

One of the cytokines with a significant role in the pathogenesis of numerous inflammatory and autoimmune diseases is tumour necrosis factor- $\alpha$ (TNF- $\alpha$ ). Binding TNF- $\alpha$ to membrane-bound receptors creates soluble forms: sTNF $\alpha$ R1 and sTNF $\alpha$ R2. Studies highlight that concentrations of STNF $\alpha R 1$ and STNF $\alpha$ R2 in the blood serum of patients with localized scleroderma correlate with their in situ expression in tissues as well as with laboratory and clinical indicators of the inflammatory condition and disease progress [9-16]. The significance of sTNF $\alpha$ R1 as a parameter determining activity, severity and therapy effectiveness for localized scleroderma has not been studied yet.

This study aims to assess the concentration of the cytokine related to one of the most important sclerodermic lesion development factors - immune system activation in patients with localized scleroderma, as well as analyse the connection between STNF $\alpha$ R1 and the clinical picture of the disease. The work investigates the correlation of sTNF $\alpha$ R1 concentration in the cases where antinuclear antibodies are present in the blood serum as well as compares receptor concentrations before and after the therapy depending on the treatment method and disease duration. The study attempts to determine whether STNF $\alpha$ R1 concentration may be a prognostic marker for the coexistence of localized scleroderma and the systemic form.

\section{Aim}

The main aim is an assessment of sTNF $\alpha$ R1 concentration in the blood serum of patients with localized scleroderma in comparison with a control group composed of healthy persons. The second goal of the study is determination of relationships between STNF $\alpha$ R1 receptor plasma concentration and disease duration, scleroderma form, the presence of antinuclear antibodies as well as the skin severity index and the skin damage index, and also assessment of STNF $\alpha$ R1 plasma concentration before and after treatment depending on the therapeutic method.

\section{Material and methods}

The study covered 41 patients with localized scleroderma: 35 women and six men aged 19-68 (mean \pm SD: $48.8 \pm 14.6$ ). The control group comprised 20 healthy persons: 12 women and eight men aged 19-68 (mean \pm SD: $47.10 \pm 14.66$ ). The patients with localized scleroderma in the studied group were treated using two methods: photochemotherapy or an antibiotic therapy (20 patients PUVA therapy, 21 patients - PNC). Topical treatment was limited to magistral greasing preparations and emollients throughout the observation period. In the case of the patients treated with intramuscularly administered procaine penicillin (dose: 2.4 million IU/day), achievement of a total dose of at least 30 million IU/day was considered as the end of the therapy. In the group of patients treated with photochemotherapy, the single initial dose during a PUVA session was $0.5 \mathrm{~J} / \mathrm{cm}^{2}$ and it was increased by $0.5 \mathrm{~J} / \mathrm{cm}^{2}$ every other day to reach the maximum value of $10 \mathrm{~J} / \mathrm{cm}^{2}$, depending on the clinical condition. The study involved three sessions a week. The session scheme, determined based on the literature data, was subsequently modified depending on the patient's individual response during the treatment. It was decided that the observation would end after 20 sessions. The patients took methoxsalen an hour before the session; its dose depended on the body weight (up to $40 \mathrm{~kg}-10 \mathrm{mg} ; 40-50 \mathrm{~kg}-20 \mathrm{mg}$; 50-60 kg - $30 \mathrm{mg}$; more than $60 \mathrm{~kg}-40 \mathrm{mg}$ ).

The study investigated patients for whom disqualifying factors were excluded and who demonstrated clinical symptoms characteristic for localized scleroderma and confirmed by a histopathological examination.

All the study participants underwent:

- determination of STNF $\alpha$ R1 blood serum concentration using the ELISA (enzyme-linked immunosorbent assay) method,

- capillaroscopy.

In the patients with LoS, the following were additionally assessed:

- clinical form of the disease (plaque, linear or generalized),

- location of skin lesions (disease foci present in the upper or lower part of the body or in both those regions),

- disease activity duration (from the appearance of the first signs/symptoms for new cases or from the moment of reactivation of previously existing LoS fociextension of lesions, appearance of erythema or intensification of skin hardening),

- skin severity index (based on mLoSSI - modified Localized Scleroderma Skin Severity Index [17]; 18 separate body areas were assessed in terms of the presence of new or extension of old lesions as well as intensification of erythema and skin hardening),

- skin damage index (based on LoSDI - Localized Scleroderma Skin Damage Index [18]; skin damage was assessed analogously to the mLoSSI scale - score: 0-3). The following features were assessed in 18 anatomical areas of the body: atrophy of skin and subcutaneous tissue as well as discolorations.

\section{Results}

Concentration analysis of the determined particle in the studied group of patients with localized scleroderma and in the control group of healthy persons

Statistically significantly higher sTNF $\alpha$ R1 concentrations were observed in the studied group of patients with 
localized scleroderma in comparison with the control group ( $p<0.005)$. Their range was 78.30-1326.50 ng/ $\mathrm{ml}$ (median: $543.50 \mathrm{ng} / \mathrm{ml}$ ) in the patients and 159.80 $349.65 \mathrm{ng} / \mathrm{ml}$ (median: $254.60 \mathrm{ng} / \mathrm{ml}$ ) in the control group (Table 1).

A statistically significant difference was established between the studied group and the control group ( $p<$ 0.005). sTNF $\alpha$ R1 values were higher in the studied group than in the control group (Table 2).

\section{sTNF $\alpha$ R1 concentration analysis in the studied group of patients with localized scleroderma depending on selected clinical parameters}

The patients participating in the study $(n=41)$ were divided into 3 subgroups depending on the clinical form of the disease. 19 persons were diagnosed with plaque scleroderma, 16 - with generalized scleroderma and 6 - with linear scleroderma. An analysis of sTNF $\alpha$ R1 concentrations depending on the LoS subtype showed no statistically significant differences.

An analysis of sTNF $\alpha$ R1 concentrations before and after treatment in the patients with localized scleroderma depending on the skin severity index (mLoSSI) revealed no statistically significant changes.

The studied group demonstrated a statistically significant positive curvilinear relationship between the skin damage index and STNF $\alpha$ R1 concentration tested after treatment completion. Patients with a higher skin damage index also had a higher blood serum concentration of the determined parameter. It was a weak correlation ( $p=0.33)$ (Table 3, Figure 1).

An analysis of STNF $\alpha$ R1 concentration depending on the disease process activity time in the studied group of patients with LoS showed no relationship between those parameters.
Analysis of the relationship between sTNF $\alpha$ R1 blood serum concentration before and after treatment and effectiveness of a given therapeutic method

The patients from the studied group were divided into two subgroups depending on the treatment method. The subgroup treated with procaine penicillin (PNC) included 21 patients and the subgroup undergoing PUVA therapy comprised 20 patients. sTNF $\alpha$ R1 blood serum concentration was determined in all the study subjects before and after treatment. The TNF $\alpha$ R1 level dropped after therapy completion in both groups, regardless of the treatment method. The difference in the determined particle level was higher in the group of patients undergoing photochemotherapy (median: $106.25 \mathrm{ng} / \mathrm{ml}$ ) than in the group taking penicillin (median: $81.50 \mathrm{ng} / \mathrm{ml}$ ) (Tables 4 and 5).

Analysis results of the skin severity index and the skin damage index depending on selected clinical parameters

Analysis of the difference between mLOSSI and mLOSDI/ LOSDI results before and after treatment depending on the therapeutic method.

Mann-Whitney $U$ test was conducted to search for any statistically significant differences between mLoSSI and $\mathrm{mLOSDI}$ results before and after treatment depending on the therapeutic method. Before the analysis, the mLOSSI score before the treatment was corrected by taking into account the presence of new foci. The analysis allows one to conclude that there are statistically significant differences in results depending on the treatment method $(p<0.05)$ (Table 6, Figures 2, 3).

The $\chi^{2}$ test, conducted to determine the possible improvement after the treatment, also showed differences

Table 1. Comparison of studied particle concentrations in the group of patients with localized scleroderma and in the control group

\begin{tabular}{lccccccccc}
\hline Group & \multicolumn{10}{c}{ sTNF $\alpha$ R1 before treatment } \\
\cline { 2 - 9 } & $\boldsymbol{N}$ & Mean & St. dev. & St. error & Min. & Q25 & Median & Q75 & Max. \\
\hline Studied & 41 & 578.79 & 229.14 & 35.79 & 78.30 & 463.50 & 543.50 & 653.50 & 1326.50 \\
\hline Control & 20 & 248.16 & 54.95 & 12.29 & 159.80 & 194.08 & 254.60 & 286.05 & 349.65 \\
\hline Total & 61 & 470.38 & 245.87 & 31.48 & 78.30 & 264.50 & 463.50 & 608.00 & 1326.50 \\
\hline
\end{tabular}

Table 2. Results of Mann-Whitney $U$ test of independence of variables, divided into the studied group and the control group

\begin{tabular}{lcccccc}
\hline & Average rank, studied & Average rank, control & $\boldsymbol{Z}$ & $\boldsymbol{P}$-value & $\boldsymbol{N}$ Studied & $\boldsymbol{N}$ Control \\
\hline sTNF $\alpha$ R1 before treatment & 40.0 & 12.6 & 5.65 & $<0.001$ & 41 & 20 \\
\hline
\end{tabular}

Table 3. Coefficients of correlation between mLoSSI and mLOSDI and sTNF $\alpha$ R1 after treatment

\begin{tabular}{lcc}
\hline & mLoSSI after treatment & mLoSDI after treatment \\
\hline sTNF $\alpha$ R1 after treatment & 0.18 & 0.33 \\
\hline
\end{tabular}



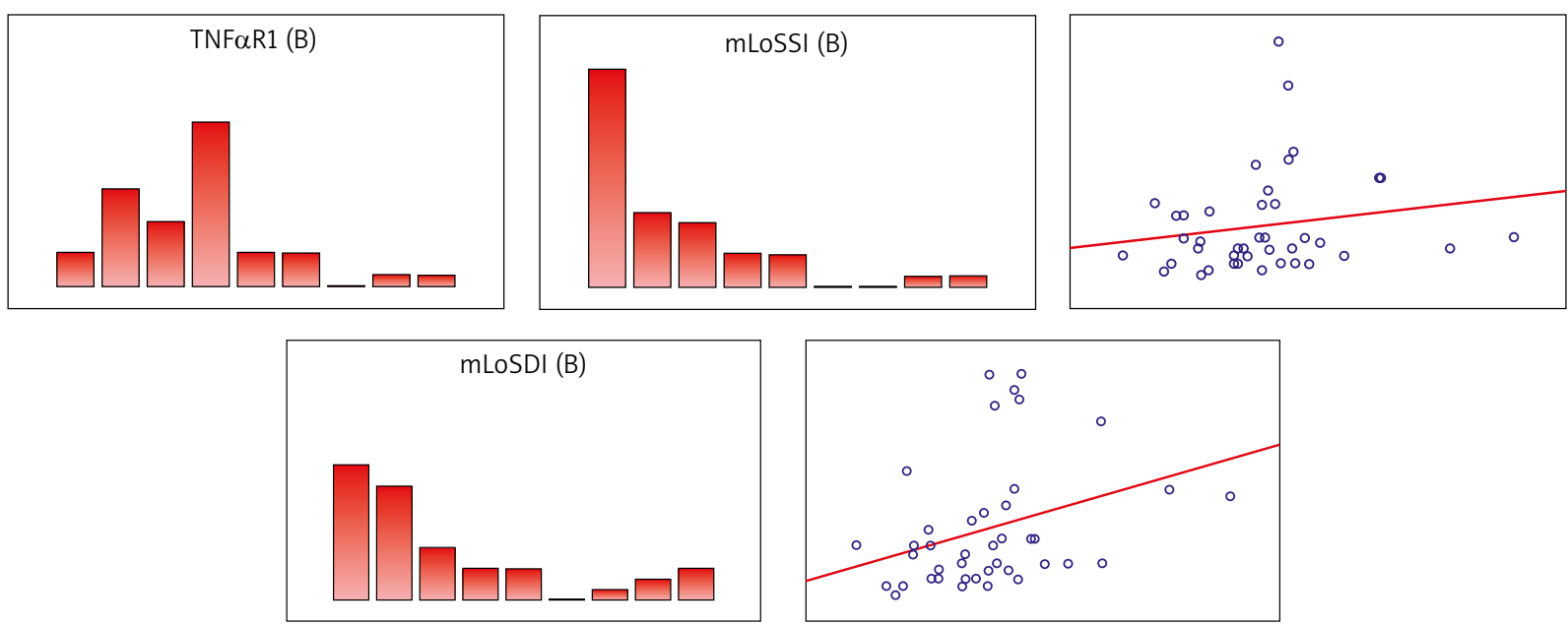

Figure 1. Scatterplot for mLoSSI and mLoSDI after treatment (B) expressed in points and sTNF $\alpha$ R1 after treatment (B)

Table 4. sTNF $\alpha$ R1 concentration difference before and after treatment depending on the treatment method

\begin{tabular}{lccccccccc}
\hline Treatment method & \multicolumn{8}{c}{ sTNF $\alpha$ R1 concentration difference before and after treatment } \\
\cline { 2 - 11 } & $\boldsymbol{N}$ & Average & St. dev. & St. error & Min. & Q25 & Median & Q75 & Max. \\
\hline PNC & 21 & 111.73 & 99.59 & 21.73 & -4.50 & 43.50 & 81.50 & 140.50 & 344.25 \\
\hline PUVA & 20 & 125.27 & 109.48 & 24.48 & 10.50 & 30.90 & 106.25 & 182.25 & 369.80 \\
\hline Total & 41 & 118.34 & 103.44 & 16.15 & -4.50 & 35.30 & 85.00 & 155.75 & 369.80 \\
\hline
\end{tabular}

Table 5. Results of Mann-Whitney $U$ test of independence of variables depending on the treatment method

\begin{tabular}{lcccccc}
\hline & $\begin{array}{c}\text { Average rank } \\
\text { PNC }\end{array}$ & $\begin{array}{c}\text { Average rank } \\
\text { PUVA }\end{array}$ & $Z$ & $P$-value & $N$ PNC & $N$ PUVA \\
\hline sTNF $\alpha$ R1 difference & 21.5 & 20.5 & 0.26 & 0.794 & 20 & 21 \\
\hline
\end{tabular}

Table 6. Results of Mann-Whitney $U$ test of independence of variables depending on the treatment method

\begin{tabular}{lcccccc}
\hline & $\begin{array}{c}\text { Average rank } \\
\text { PNC }\end{array}$ & $\begin{array}{c}\text { Average rank } \\
\text { PUVA }\end{array}$ & $Z$ & P-value & $\begin{array}{c}\text { Number of patients } \\
\text { treated with PNC }\end{array}$ & $\begin{array}{c}\text { Number of patients treated } \\
\text { with PUVA }\end{array}$ \\
\hline mLoSSI & 14.4 & 28.0 & -3.66 & 0.000 & 21 & 20 \\
\hline$m$ LoSDI & 14.2 & 28.2 & -3.87 & 0.000 & 21 & 20 \\
\hline
\end{tabular}

between the two therapies. A higher improvement rate was obtained for PUVA. Nineteen out of 20 study subjects undergoing PUVA therapy demonstrated a decrease in the skin severity index. A skin damage index decrease was observed in 17 out of 20 patients treated using that method. Most patients taking procaine penicillin showed no improvement after treatment completion. Both the skin severity index (mLoSSI) and the skin damage index (mLoSDI) show a moderate relationship between the improvement of results and the treatment method (Tables 7 and 8).

Influence of the clinical subtype of localized scleroderma on the parameter analysis results

Antinuclear antibodies (ANA) were most commonly positive in the patients with the generalized subtype of scleroderma. Approximately a half of the patients with that disease form showed a positive result. The titre of those antibodies was also positive in $31.3 \%$ of patients with the plaque form, while the patients with the linear subtype had no ANA at all (Table 9).

No relationship was observed between the clinical subtype of the disease and the presence of a positive titre of Scl-70, ACA and RNA antibodies.

\section{Discussion}

Many cytokines may participate in the pathogenesis of localized scleroderma by stimulating the synthesis of other pro-inflammatory particles, reducing the activity of extracellular matrix metalloproteinases, stimulating 


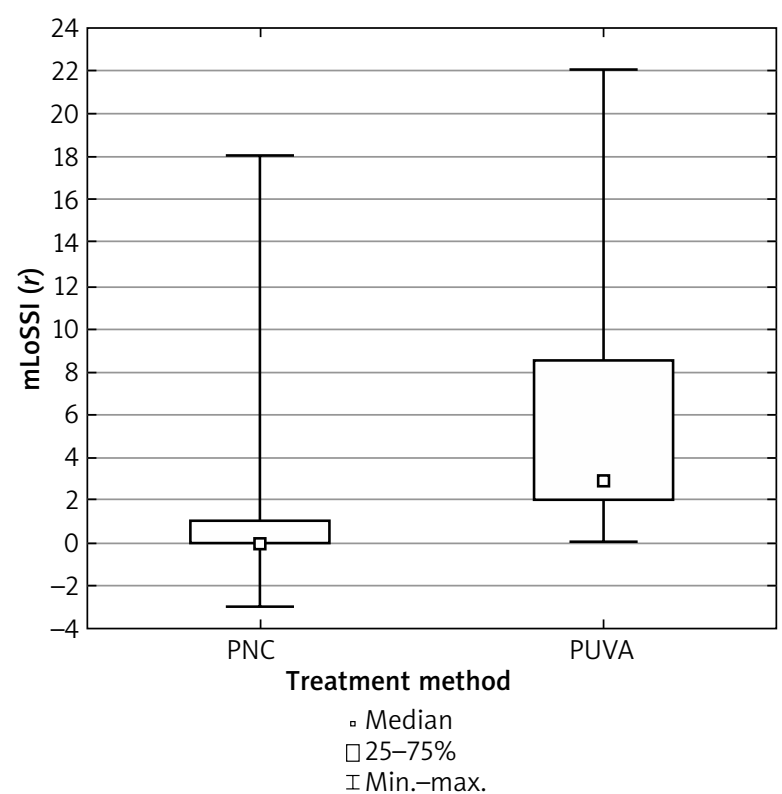

Figure 2. Order statistics for mLoSSI score differences before and after treatment depending on the treatment method

Table 7. Disease severity change before and after treatment assessed using the mLoSSI scale depending on the treatment method.

\begin{tabular}{lccc}
\hline \multirow{2}{*}{ Score difference for mLoSSI } & \multicolumn{3}{c}{ Treatment method } \\
\cline { 2 - 4 } & PNC & PUVA & Total \\
\hline $\begin{array}{l}\text { No improvement } \\
\text { after treatment }\end{array}$ & $14(93.3 \%)$ & $1(6.7 \%)$ & 15 \\
\hline Improvement after treatment & $7(26.9 \%)$ & $19(73.1 \%)$ & 26 \\
\hline Total & $21(51.2 \%)$ & $20(48.8 \%)$ & 41 \\
\hline$\chi^{2}$ & 14.238 & & \\
\hline$P$-value & $<0.001$ & & \\
\hline$V$ & 0.589 & & \\
\hline
\end{tabular}

Table 9. The presence of ANA depending on the clinical subtype of the disease

\begin{tabular}{lccc}
\hline LoS form & \multicolumn{3}{c}{ ANA } \\
\cline { 2 - 4 } & $(-)$ Negative & $(+)$ Positive & Total \\
\hline Plaque & $11(68.8 \%)$ & $5(31.3 \%)$ & 16 \\
\hline Generalized & $10(52.6 \%)$ & $9(47.4 \%)$ & 19 \\
\hline Linear & $6(100.0 \%)$ & $0(0.0 \%)$ & 6 \\
\hline Total & 27 & 14 & \\
\hline$\chi^{2}$ & 4.648 & & \\
\hline$P$-value & 0.098 & & \\
\hline$V$ & 0.337 & \\
\hline
\end{tabular}

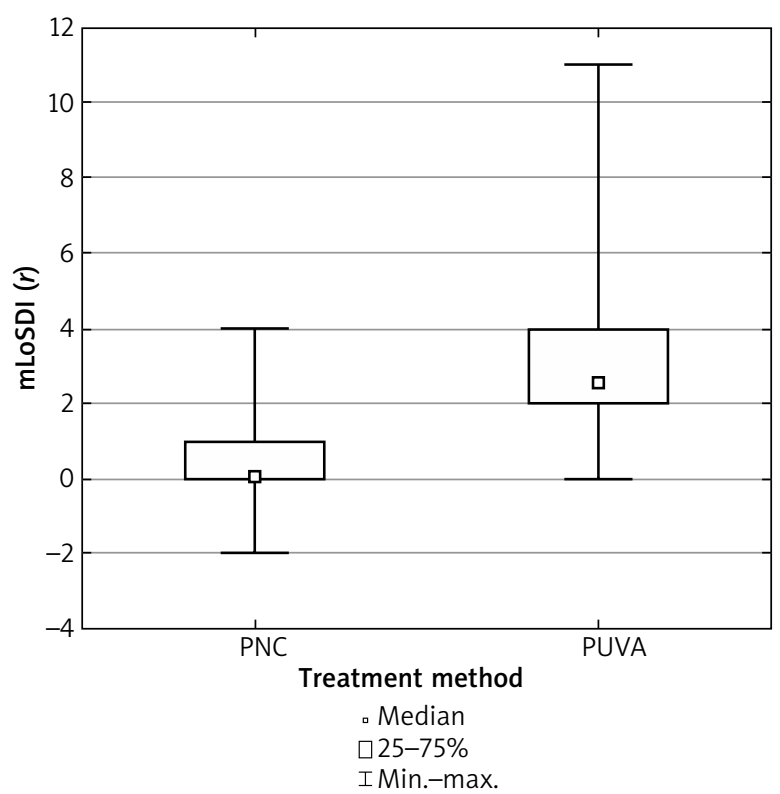

Figure 3. Order statistics for mLoSDI score differences before and after treatment depending on the treatment method

Table 8. Skin damage index change before and after treatment assessed using the mLOSDI scale depending on the treatment method

\begin{tabular}{lccc}
\hline \multirow{2}{*}{ Score difference for mLoSDI } & \multicolumn{3}{c}{ Treatment method } \\
\cline { 2 - 4 } & PNC & PUVA & Total \\
\hline $\begin{array}{l}\text { No improvement } \\
\text { after treatment }\end{array}$ & $15(83.3 \%)$ & $3(16.7 \%)$ & 18 \\
\hline Improvement after treatment & $6(26.1 \%)$ & $17(73.9 \%)$ & 23 \\
\hline Total & $21(51.2 \%)$ & $20(48.8 \%)$ & 41 \\
\hline$\chi^{2}$ & 11.052 & & \\
\hline$P$-value & 0.001 & & \\
\hline$V$ & 0.519 & & \\
\hline
\end{tabular}

the proliferation of fibroblasts and inducing the expression of adhesive particles on endothelial cells. Numerous publications on soluble tumour necrosis factor- $\alpha$ (TNF- $\alpha$ ) receptor type I point to the enormous role of that cytokine in the pathogenesis of connective tissue diseases, but that role has not been investigated yet in patients with localized scleroderma. In systemic scleroderma (SSc), the highest concentrations of sTNF $\alpha$ R1 have been observed in patients with a fast progression of organ lesions. Moreover, it has been established that sTNF $\alpha$ R1 concentration in the initial phase of disease development positively correlates with the Scleroderma Skin Severity Index (skin cores). Higher STNF $\alpha$ R1 values in SSc patients with a shorter duration of Raynaud's phenomenon confirm the value of that clinical parameter as a prognostic factor of faster disease progression. The obtained results point to the possibility of using sTNF $\alpha$ R1 concentration 
determination for assessing the activity and severity of systemic scleroderma $[9,10]$, but this has not been investigated for the skin form thus far.

The range of publications on morphea is much smaller. Based on the undeniable similarity of the molecular mechanisms leading to excessive fibrosis in both those disease entities and on the available literature, the described study assessed the significance of the TNF $\alpha-$ STNF $\alpha$ R1 signalling pathway in the course of localized scleroderma.

An assessment of sTNF $\alpha$ R1 concentration in patients treated with two different methods allowed one to compare those strategies and might allow one to make an individual choice of the best therapy in the future depending on the correlation between the studied parameters. The obtained results provide new information on the potential mechanisms leading to localized scleroderma and make the hypothesis of a close relationship between that disease and the systemic form of scleroderma less probable.

The presented own study revealed increased sTNF $\alpha$ R1 concentrations in the patients with localized scleroderma in comparison with a control group of healthy volunteers. The analysis showed no correlation between the concentration of the studied cytokine and the skin severity index in localized scleroderma. This points to the role of sTNF $\alpha$ R1 in the pathogenesis of the disease.

The significant role of sTNF $\alpha$ R1 as an immune system activity marker in scleroderma was confirmed both in the previous publications and own research. The conducted analysis proved the correlation between sTNF $\alpha$ R1 concentration and the skin damage index. Therefore, it seems a valuable prognostic factor, useful in anticipating the further course of the disease. No relationship between STNF $\alpha$ R1 concentration and disease duration or clinical subtype of scleroderma was determined.

In more severe cases, Braun-Falco recommends intramuscular administration of procaine penicillin (dosage: 2,400,000 units a day) until a total dose of approx. 30 million units is reached [6]. Based on the results obtained in the own study, PUVA photochemotherapy seems to be a better therapeutic strategy compared with procaine penicillin. Patients treated with PUVA sessions demonstrated a greater decrease in STNF $\alpha$ R1 concentration and an improvement of the clinical condition after therapy completion. PUVA therapy is a recognized method of LoS treatment as confirmed in numerous scientific publications [19-21].

One has to state that LoS and SSc are entirely different disease entities, but they may share certain pathophysiological and genetic pathways [22]. The probability of localized scleroderma transformation into the systemic form of the disease is slight. According to various sources, that risk equals 0.9 to $5.7 \%[5,23]$. In a big randomized study, the presence of typical morphea foci was determined only in 12 (3.2\%) out of 370 patients with systemic scleroderma (mainly the IcSSc form). It was also established that generalized localized scleroderma was developed earlier than SSc or simultaneously with SSc. Overlapping of several non-skin diseases in the picture of localized scleroderma is always a threat of disease progression. However, internal organs are usually affected less severely in morphea than in the systemic form. Patients with localized scleroderma often require specialized dermatological, orthopaedic, ophthalmological, neurological and rheumatological care as well as intense physiotherapy.

\section{Conclusions}

STNF $\alpha$ R1 concentration in the blood serum of patients with localized scleroderma is statistically significantly higher in comparison with the control group. This points to the role of sTNF $\alpha R 1$ in the pathogenesis of the disease. sTNF $\alpha$ R1 concentration correlates with the skin damage index and therefore is a valuable prognostic factor, useful in anticipating the further course of the disease. No relationship between STNF $\alpha$ R1 concentration and disease duration, clinical subtype of scleroderma or the skin severity index was determined. Patients treated with PUVA demonstrate greater drops of sTNF $\alpha$ R1 concentration in plasma after therapy completion in comparison with the group treated with PNC. Generalized LoS demonstrated the highest skin severity index and a positive titre of antinuclear antibodies (ANA).

\section{Conflict of interest}

The authors declare no conflict of interest.

\section{References}

1. Fett NM. Morphea (localized scleroderma). JAMA Dermatol 2013; 149: 1124.

2. Kreuter A. Localized scleroderma. Dermatol Ther 2012; 25: 135-47.

3. Lis-Święty A, Brzezińska-Wcisło L. Twardzina układowa czynniki prognostyczne, aktywność i ciężkość choroby. Przegl Dermatol 2010; 97: 398-405.

4. Lis-Święty A, Skrzypek-Salamon A, Ranosz-Janicka I, et al. Localized scleroderma: clinical and epidemiological features with emphasis on adulthood - versus childhood - onset disease differences. J Eur Acad Dermatol Venereol 2017; 31: 1595-603.

5. Careta MF, Romiti R. Localized scleroderma: clinical spectrum and therapeutic update. An Bras Dermatol 2015; 90 : 62-73.

6. Braun-Falco O, Plewig G, Wolff HH, et al. Dermatologia. Wydawnictwo Czelej, Lublin 2010.

7. Fett N, Werth VP. Update on morphea: part I. Epidemiology, clinical presentation, and pathogenesis. J Am Acad Dermatol 2011; 64: 217-28.

8. Lis-Święty A, Brzezińska-Wcisło L, Bergler-Czop B, et al. Badanie stężenia rozpuszczalnego receptora czynnika martwicy nowotworów alfa typu I w surowicy chorych 
z twardziną układową przed i po leczeniu immunosupresyjnym. Przegl Dermatol 2006; 93: 335-40.

9. Lis A, Brzezińska-Wcisło L. Rozpuszczalne receptory dla cytokin w surowicach chorych z twardziną układową - korelacje kliniczne. Wiad Lek 2003; 56: 532-6.

10. Lis-Swiety A, Gola J, Mazurek U, et al. Measuring mRNA level expression of tumor necrosis factor alpha and its receptors related genes in patients with systemic sclerosis. J Dermatol Sci 2010; 59: 145-7.

11. Majewski S, Wojas-Pelc A, Malejczyk M, et al. Serum levels of soluble TNF alpha receptor type I and the severity of systemic sclerosis. Acta Derm Venereol 1999; 79: 207-10.

12. Wojas-Pelc A, Majewski S, Malejczyk M, et al. Parametry odczynowość komórkowej w twardzinie układowej - korelacje kliniczne. Przegl Dermatol 1999; 86: 543-9.

13. Brzezińska-Błaszczyk E, Pietrzak A, Misiak-Tłoczek AH. Tumor necrosis factor (TNF) is a potent rat mast cell chemoattractant. J Interferon Cytokine Res 2007; 27: 911-9.

14. Pehlivan Y, Onat A, Ceylan N, et al. Serum leptin, resistin and TNF-alpha levels in patients with systemic sclerosis: the role of adipokines in scleroderma. Int J Rheum Dis 2012; 15: 374-9.

15. Mastrofrancesco A, Alfè M, Rosato E, et al. Proinflammatory effects of diesel exhaust nanoparticles on scleroderma skin cells. J Immunol Res 2014; 2014: 751.

16. Arkachaisri T, Vilaiyuk S, Li S, et al. The localized scleroderma skin severity index and physician global assessment of disease activity: a work in progress toward development of localized scleroderma outcome measures. J Rheumatol 2009; 36: 2819-29.

17. Arkachaisri T, Vilaiyuk S, Torok KS. Development and initial validation of the Localized Scleroderma Skin Damage Index and Physician Global Assessment of disease Damage: a proof-of-concept study. Rheumatology 2010; 49: 373-81.

18. Fett NM. Morphea: evidence-based recommendations for treatment. Indian J Dermatol Venereol Leprol 2012; 78: 135-41.

19. Usmani N, Murphy A, Veale D, et al. Photochemotherapy for localized morphoea: effect on clinical and molecular markers. Clin Exp Dermatol 2008; 33: 698-704.

20. Kerscher M, Meurer M, Sander C, et al. PUVA bath photochemotherapy for localized scleroderma. Evaluation of 17 consecutive patients. Arch Dermatol 1996; 132: 1280-2.

21. Gupta RA, Fiorentino D. Localized scleroderma and systemic sclerosis: is there a connection? Best Pract Res Clin Rheumatol 2007; 21: 1025-36.

22. Chung L, Lin J, Furst DE, et al. Systemic and localized scleroderma. Clin Dermatol 2006; 24: 374-92.

23. Chen JK, Chung L, Fiorentino DF. Characterization of patients with clinical overlap of morphea and systemic sclerosis: a case series J Am Acad Dermatol 2016; 74: 1272-4. 